\title{
Pedagogic Qualification of Higher Education Teaching Staff - The Third Wave
}

\author{
http://dx.doi.org/10.3991/ijep.v3i4.3069 \\ José Couto Marques \\ Universidade do Porto, Porto, Portugal
}

\begin{abstract}
The process triggered by the Bologna Declaration has been producing significant results of various types in the EU Higher Education sector. After reviewing some of the consolidated outcomes of this process, reference is made to a novel trend that has emerged recently and which is geared towards the requirement that by 2020 all staff teaching in higher education institutions should have received certified pedagogical training. A description is provided of initiatives within the field of Engineering Education promoted by institutions that have been actively pursuing this precise objective for the past few decades.
\end{abstract}

Index Terms-Engineering Education; pedagogical qualification; Ing Paed IGIP

\section{INTRODUCTION}

Higher Education in the European Union (EU) has been the object of successive waves of accreditation/qualification initiatives. Some of these were general in scope while others have been specifically directed towards Engineering Education.

The first wave dealt with the initial impact of the Bologna process, the introduction of ECTS and the implementation of course accreditation procedures at national level.

The second wave involved course accreditation at European level. In the engineering area this has been handled by ENAEE (European Network for Accreditation of Engineering Education) and has led to the award of the EUR-ACE quality label.

A third wave is now emerging at EU level whose focus is the mandatory didactic/pedagogic qualification/accreditation of higher education teaching staff.

This paper traces these recent European developments and their antecedents at global level, with a special focus on the issues pertaining to the pedagogic qualification initiatives, particularly in the field of Engineering Education.

\section{THE FIRST WAVE}

The Bologna Process, initiated with the signature in June 1999 of the Bologna Declaration [1], has led to the establishment of a European Higher Education Area and to the coordination of the actions carried out in this frame by the participant countries, aiming to increase the international competitiveness of the European higher education system.

The three overarching objectives of the Bologna Process comprised the introduction of the three cycle system (bachelor/master/doctorate) and of quality assurance and qualification recognition procedures which are instrumental to foster student mobility and flexible learning paths.

Course accreditation at national level have been carried out in Portugal since 1994, with the involvement of OE ("Ordem dos Engenheiros"), the national engineering professional body. Subsequently and in compliance with Bologna Process guidelines, a national agency had been created in 2007 to perform this task for all higher education courses, the A3ES (Agency for Assessment and Accreditation of Higher Education) [2].

It is worth mentioning at this point that in the United States the first evaluations of engineering degree programs have been carried out in 1936 by ECPD (Engineers' Council for Professional Development), an institution dedicated to the education, accreditation, regulation and professional development of engineering professionals and students. In 1980 ECPD was renamed ABET (Accreditation Board for Engineering and Technology) [3].

\section{THE SECOND WAVE}

ENAEE was founded in 2006, with the Portuguese $\mathrm{OE}$ as one of the 14 founding members [4]. ENAEE is the European body responsible for authorising national accreditation agencies to award the EUR-ACE® quality label to first and second cycle engineering programs which they have accredited in accordance with the EURACE Standards [5].

FEUP is very proud to be the Portuguese Higher Education Institution with the largest number of EURACE accredited courses. At the end of June 2013 three additional second cycle courses have been awarded the EUR-ACE label, increasing the FEUP total to ten: the Integrated Masters in Mechanical Engineering, Civil Engineering, Chemical Engineering, Informatics and Computing Engineering, Electrical and Computers Engineering, Industrial Engineering and Management, Environmental Engineering, Metallurgical and Materials Engineering, Bioengineering and the Master in Mining and Geo-Environmental Engineering. In all cases accreditation has been granted for a six year period [6]. 
The EUR-ACE label is internationally recognized, which facilitates academic and professional mobility and increases the value, the reputation and the competitiveness of graduates from EUR-ACE labeled engineering schools in the global job market.

\section{THE THIRD WAVE}

After the accreditation of courses, first at national level and subsequently at EU level, a new initiative has been set in motion in the European arena whose repercussions will undoubtedly be felt in HEI involved in Engineering Education across the continent.

In a Press Release issued in 18 June 2013 [7] the European Commission announced the publication of the first report of the EU High Level Group on Modernization of Higher Education entitled "Improving the quality of teaching and learning in Europe's higher education institutions" [8].

This High Level Group has been set up by the European Commissioner for Education, Culture, Multilingualism, Youth and Sport, Ms. Androulla Vassiliou, in the context of the European Agenda for the Modernisation of Higher Education [9-12] put forward in 2011 , in the wake of the Europe 2020 strategy whose aim is to have at least $40 \%$ of $30-34$ years old in the EU in possession of a university-level qualification by 2020 . In a preamble to the Report Ms. Vassiliou states that "[...] quality higher education teaching is absolutely crucial in enabling our higher education institutions to produce the critically-thinking, creative, adaptable graduates who will shape our future. And yet, while it should be the centre of gravity of higher education, the quality of teaching in our universities and colleges is often overlooked and undervalued."

The 8-member High Level group is chaired by Professor Mary McAleese, former President of Ireland, and integrates very senior, experienced and prestigious elements from academia and industry.

Their Report lists 16 recommendations, among which are a call for mandatory certified training for professors and other higher education teaching staff, more efforts in helping students develop entrepreneurial and innovative skills and the creation of a European Academy of Teaching and Learning.

It is worth transcribing some of the recommendations verbatim, given their direct relation to the quality of teaching and the pedagogic qualification of teaching staff.

Recommendation 2 - "Every institution should develop and implement a strategy for the support and ongoing improvement of the quality of teaching and learning, devoting the necessary level of human and financial resources to the task, and integrating this priority in its overall mission, giving teaching due parity with research."

Recommendation 4 - "All staff teaching in higher education institutions in 2020 should have received certified pedagogical training. Continuous professional education as teachers should become a requirement for teachers in the higher education sector."

Recommendation 5 - "Academic staff entrance, progression and promotion decisions should take account of an assessment of teaching performance alongside other factors."

Recommendation 14 - "The European Union should support the establishment of a European Academy for Teaching and Learning led by stakeholders, and inspired by the good practices reflected in this report."

\section{PEDAGOGICAL QuALIFICATION OF ENGINEERING EDUCATORS}

In this moment when the EU defines the certified pedagogic qualification of teachers in all higher education areas as an objective to be achieved by 2020 , it is timely to review how such concerns have been taken into account in the specific field of Engineering Education by presenting a concise historical panorama of initiatives that have been carried out during the past 40 years, firstly in the European context and then within a wider geographic range.

It is most appropriate to start by highlighting the important and pioneering role played by Professor Adolf Melezinek [13] of Klagenfurt University in Austria in the establishment of the connection between pedagogy and engineering education. His studies and publications about this theme have created the dynamic that led him in 1972 to the foundation of the International Society for Engineering Education - IGIP-(Internationale Gesellschaft für Ingenieurpädagogik), that he headed for many years and of which he is now Honorary Life President. His book "Engineering Pedagogy" [14], published in 1977 and translated into many languages, provides a synthesis of the main features of his methodology.

The establishment of an engineering pedagogy has been one significant step ahead at a time when engineering and pedagogy had not yet been the object of a proper connection in scientific terms. IGIP has been actively engaged since its foundation in the development of a vast range of initiatives focused on the improvement of teaching and learning methods for engineering subjects.

Among them stands out the ING PAED IGIP - International Engineering Educator Diploma, which is awarded after completion at an IGIP accredited Training Centre of a modular curriculum which covers in a very comprehensive manner the most relevant components of engineering pedagogy.

The ING PAED IGIP Diploma, besides confirming a higher degree of proficiency as an engineering educator, also facilitates the international recognition of teaching qualifications, making it a valuable supporting element to teacher mobility in the global job market.

At present the number of ING PAED IGIP holders exceeds 1200 in over 30 countries in Europe, America, Africa and Asia. 


\section{IGIP VS. THE HIGH LEVEL GROUP}

In the area of Engineering Education in Europe the pedagogical qualification of teaching staff has an accumulated experience of several decades, supported by organizational structures that control the accreditation processes of training centres and the award of diplomas that certify the acquisition of advanced teaching skills to members of academe who invest in those specific aspects of their personal and professional development. IGIP has been playing a major role in this endeavour since its foundation in 1972 .

The EU target, expressed in the Report of the High Level Group, that by 2020 all staff teaching in higher education institutions should have received certified pedagogical training, is undoubtedly very laudable and represents another positive step in the process set in motion in 1999 by the Bologna Declaration.

The Report, which is to be followed by subsequent documents, has resulted from the work developed from September 2012 to June 2013 by the 8 members of the High Level Group, having held 4 meetings for which were invited a total of 15 experts from several universities, ministries and European agencies.

It is too early for having concrete data available concerning the reaction to this Report from HEIs in the EU (and also from other continents).

After this first general and comprehensive approach to the complete spectrum of higher education in its full range, it is natural and desirable that the focus will be narrowed to identify in a systematic manner the state of affairs concerning pedagogical teacher qualification in each specific scientific area of the higher education universe.

In our condition of Engineer Educators we must therefore be attentive to the dialogue and to the desirable interaction which is hoped to exist and expected to be launched in the very near future between the EU High Level Group for the Modernisation of Higher Education and institutions such as the International Society for Engineering Education - IGIP, whose wealth of experience, amassed in the course of 40 years of active presence in over 30 countries, represents an invaluable asset that should be called to play a major role in the next phases of this important process, whose inception we have tried to highlight in this document.

\section{REFERENCES}

[1] http://www.ond.vlaanderen.be/hogeronderwijs/bologna/links/lang uage/1999_Bologna_Declaration_Portuguese.pdf, accessed June 2013.

[2] http://www.a3es.pt/en

[3] http://abet.org/History/, accessed June 2013.

[4] http://www.enaee.eu/

[5] http://www.enaee.eu/eur-ace-system/eur-ace-frameworkstandards, accessed June 2013.

[6] http://enaee.trynisis.com/index.php?id=1\&tx_umeurace[term]=por to - faculdade\&tx umeurace[sens] $=1 \&$ tx umeurace[ord] $=$ sname \&tx umeurace[in] $=1$, accessed June 2013.

[7] EC Press Release IP/13/554, "EU high level group: train the professors to teach," http://europa.eu/rapid/press-release IP-13554 en.htm, accessed June 2013.

[8] High Level Group on the Modernisation of Higher Education, Report to the European Commission on Improving the Quality of Teaching and learning in Europe's Higher Education Institutions, June 2013, http://ec.europa.eu/education/higher-education/doc/ modernisation_en.pdf, accessed June 2013.

[9] EC Memo/11/613, "Modernising higher education - facts and figures," http://europa.eu/rapid/press-release MEMO-11-613 en. htm?locale=EN, accessed June 2013.

[10] EC Memo/11/615, "An EU strategy for modernising higher education - Questions and Answers,"

http://europa.eu/rapid/press-release_MEMO-11615 en.htm?locale=EN, accessed June 2013.

[11] EC Press Release IP/11/1043, "Modernisation and employability at heart of new higher education reform strategy," http://europa.eu/rapid/press-release_IP-111043 en.htm?locale=EN, accessed June 2013.

[12] http://ec.europa.eu/education/highereducation/doc/com0911 en.pdf, accessed June 2013.

[13] V. Prikhodko, "Adolf Melezinek and Engineering Pedagogy," Proc. $41^{\text {st }}$ Int. Conf. on Engineering Pedagogy, Villach, Austria, 2012.

[14] A. Melezinek, Ingenieurpädagogik: Grundlagen Einer Didaktik Des Technik-Unterrichtes, Springer-Verlag, Wien, New York, 1977. http://dx.doi.org/10.1007/978-3-7091-3290-6

\section{AUTHORS}

José Couto Marques is with the Departamento de Engenharia Civil, Faculdade de Engenharia, Universidade do Porto, Porto, Portugal, jmarques@fe.up.pt.

Submitted 29 July 2013. Published as re-sunmitted by the author 11 October 2013 